\title{
Amidst a Global Trade War: China, Japan and the United States and the Comprehensive and Progressive Agreement for a Transpacific Partnership
}

\author{
Mathieu Arès ${ }^{1}$, Éric Boulanger² \\ ${ }^{1}$ Université de Sherbrooke, Sherbrooke, Canada \\ ${ }^{2}$ Université du Québec à Montréal, Montreal, Canada \\ Email: mathieu.ares@usherbrooke.ca
}

How to cite this paper: Arès, M., \& Boulanger, É. (2020). Amidst a Global Trade War: China, Japan and the United States and the Comprehensive and Progressive Agreement for a Transpacific Partnership. Open Journal of Political Science, 10, 61-81. https://doi.org/10.4236/ojps.2020.101006

Received: November 29, 2019

Accepted: December 28, 2019

Published: December 31, 2019

Copyright $\odot 2020$ by author(s) and Scientific Research Publishing Inc. This work is licensed under the Creative Commons Attribution International License (CC BY 4.0).

http://creativecommons.org/licenses/by/4.0/

\begin{abstract}
Due to the US withdrawal from the Trans-Pacific Partnership (TPP), the remaining 11 partners entered into a new trade agreement, renamed the Comprehensive and Progressive Trans-Pacific Partnership (CPTPP) in January 2018. In this text we examine the reasons why the "orphans" of the TPP decided to save the agreement under a different version by first examining the two dominant explanatory models, realism and functionalism, and then proposing a complementary one that emphasizes the need for a strong legal and normative framework to promote the integration of mid-powers into trans-Pacific and even global value chains. This text also illustrates the unique leadership and activism of Japan in the negotiation process.
\end{abstract}

\section{Keywords}

TPP, Regionalism, Global Value Chain, Japan, Trade Negotiation

\section{Introduction}

Despite the US decision to withdraw from the Trans-Pacific Partnership (TPP) in January 2017, the "orphans" of the TPP, the other 11 countries that were part of the original agreement ${ }^{1}$, did not give up and quickly returned to the negotiating table to reach, one year later, a new agreement, known as the "Comprehensive and Progressive Agreement for a Transpacific Partnership" (СРTPP). This post-American version of the TPP retained most of its original content apart ${ }^{1}$ These 11 countries are: Australia, Brunei, Canada, Chile, Japan, Malaysia, Mexico, New Zealand, Peru, Singapore and Vietnam. 
from minor modifications to accommodate some members changing interests in light of the American withdrawal and to prepare the agreement both for the expansion of its membership and for the return of the United States into it, which is now a very unlikely prospect ${ }^{2}$.

The US withdrawal should not be considered as just one of Trump's many whimsical and erratic gestures. It is an attribute of a troublesome trajectory that the world economy is taking and it indicates that there are political forces at work within the global economy that are choosing to ignore that in production and trade today, competitiveness is no longer strictly measured on a national basis but on a global one. Moreover, these forces are pushing states to ensure the competitiveness of their economies by attempting to redefine the rules of world trade, opposing the enduring expansion of value chains and production and trade networks to promote instead a renationalization of economic capacities. President Donald Trump and others believe that the United States cannot prosper in a global economy characterized by a high level of interdependence. To address this situation, they aim to "renationalize" the instruments of competitiveness and renegotiate the existing and forthcoming trade agreements on a bilateral basis to ensure not only large economic gains but also security from the havoc of multilateralism and interdependence, from which derived the United States economic problems, if we are to read correctly into Trump's thought ${ }^{3}$.

The fact that the United States has not joined the CPTPP and has no intent to do so, preferring bilateral trade agreements, shows that those forces calling for renationalization are more than a fad, and wish to change the rules of the game at the risk of heading straight into a global trade war. President Trump is ignoring former President Obama's position on the TPP, which was the opposite of his own. For Obama, this agreement was nothing less than the "legal outpost" from which the United States could project its trade rules and principles and counter the growing influence of China's actions while taking into account the fact that the high level of economic interdependence and connectivity between Asia-Pacific economies required a level playing field-an informal norm that can be easily by-passed however-that China's economic rise could be threatened if it didn't embrace it (Nathan, 2016). President Obama made it clear in an interview with The Wall Street Journal: "If we do not write the rules, China will write out the rules for that region [Asia-Pacific]" and American business and American agriculture "will be shut out" (Seib, 2015). This now famous statement indicates two factors in connection with our reasoning on trade agreements, on the status of the world economic order and on the difficult and quite sensitive position Japan has found itself in since the United States withdrawal.

${ }^{2}$ The "orphans" of the TPP met on July 12 and 13, 2017 in Hakone, Japan, where they agreed to "save" the treaty, without seeking to make too many revisions to keep intact the spirit and letter of the treaty, even as to "freeze" certain clauses. Negotiations resumed in August 2017 and on the margins of the APEC Summit in Da Nang, Vietnam in November 2017. The agreement was finally concluded on February 12, 2018 and signed in Santiago, Chile on March 8, 2018.

${ }^{3}$ For example, in a short-sighted mercantilist grasp on trade "Trump's trade advisors conclude that when a country imports more than it exports, it lowers its economic growth" ignoring the large benefits of global values chains for the American economy. See, Solis \& Urata, 2018: p. 115. 
First, trade agreements have become major economic partnerships that go far beyond liberalizing trade in goods and services, but encompassing all factors of production and competition-from labour standards to investment protection to intellectual property rights (IPR), etc.- -which require a universal rules-based economic order with a high level of "normativity". It is no coincidence, therefore, that at the signing in Tokyo of the new partnership between Japan and the European Union (EU) in July 2018, leaders of both sides emphasized values such as liberal democracy or human rights and called for an economic order based on these rules. Prime Minister Shinzo Abe also declared his commitment to a "just and equitable" liberal order. ${ }^{4}$

Secondly, Obama's statement indicates the possible emergence of a "parallel" international order under China's direct influence (Stuenkel, 2016). While it is not necessarily a non-liberal order (Boyle, 2016), China now possessed the commercial, financial and technological capacities and aptitudes to implement "idiosyncratic" rules—which are not "amenable to diffusion" (Solis, 2017) — for trade in goods and services, for foreign investment or for financial cooperation, to name just a few fields in which China is active today (Heilmann et al., 2014). Those rules, as Oliver Stuenkel reminds us, might be promoted as being liberal for they favour, for example, a higher volume of trade, but they are constantly adjusted to the requirement of China's aspirations as a great power and are not set up to create a level playing field. Therefore the actions taken by China, for example, in its trade policy, more specifically in its Road and Belt Initiatives (OBOR), or in relation to the establishment of new international organizations, are consistent with its national interest in opposing rules, institutions and organisations that have the potential to reign in its economic power, while using and even promoting those who are giving Chinese firms a clear advantage. We could it call it a parallel order à la carte, built according to the economic requirements of China first, and its partners, second. The American behaviour accentuates this parallel order's attractiveness, especially for countries that are considering bilateral and circumscribed agreements as a more advantageous option than multilateral and multifaceted economic partnerships. Furthermore, nationalism and populism solidify this parallel order, since it could represent a rebalancing of power relations within globalization, which has been perceived as mostly beneficial to Western Countries (despite what President Trump thinks) but at the risk of strengthening the "forces of fragmentation and division" within the world economy, uniting large segments of population in South and the North in their fear of weakening sovereignty, degrading environmental standards or fast rising inequalities.

In this paper, we examine the reasons why the TPP countries decided to save the agreement. We do this by first examining the two dominant explanatory models, realism and functionalism, and then proposing a complementary one ${ }^{4}$ Kantei, 2018.

${ }^{5}$ Of course, it is the case for many trade agreements, but in the case of China, it has consequences beyond, for example, requesting particular rules for a sensitive sector, a common practice in bilateral FTA negotiated by Japan. 
that emphasizes the need for a strong legal and normative framework to promote the integration of mid-powers into trans-Pacific and even global value chains. Without underestimating the importance of Australia, New Zealand and Vietnam in the conclusion of the CPTPP, we then propose to examine in more detail the particular leadership of Japan, which has helped to revive the negotiations and bring about the ratification of the CPTPP. Our general thesis is that Japan wants to multilateralize its trade policy on rules and norms to circumscribed Chinese and American unilateralism in Asia-Pacific and to show a certain level of activism to counter the potential negative effects of a China-America trade war on global economic growth.

\section{The Trans-Pacific Partnership: Two Models of Analysis}

\subsection{The Realist Perspective}

A large segment of political economy analysis devoted to understanding the TPP adopts a broad realist perspective or a security and strategic vision, which highlight a hegemonic rivalry between the United States and China ${ }^{6}$. The main idea is that the agreement serves to "contain" the Chinese challenger by imposing a set of "commercial gold rules," covering labour, state-owned companies, foreign direct investment, intellectual property, environmental standards and pharmaceutical industries, to name just a few. Indeed, as we have pointed out, President Obama has never hidden his preference for a robust rules-based international order and the fact that the TPP reinforces and sustains the legitimacy of this prospect. The Obama administration aimed to support and foster American firms in Asia-while embracing the rules of globalisation-induced competitiveness-in the face of an increasingly competitive and unsatisfied China, which is now the first or second economic partner of most countries around the Pacific (Arès et al., 2016a). President Trump's rejection of the TPP does not hide the fact that there is a political-legal clash on the economic regulation of globalisation between, on the one hand, the United States, Japan, the EU and, as we suggest, a number of medium-sized powers like Canada-the champions of strong legalism and rigorous global liberal regulation for trade-and, on the other hand, China, together with potentially several other countries who feel left out of global prosperity or are at a serious disadvantage in global competition like Russia, India, Brazil and other developing countries. The leaders and elite of the later group of countries view a post-American world order based on pragmatic integration, centred on vague principles and malleable and adaptable to national issues and interests, as potentially a more secure way to promote economic development and growth and simultaneously to lock in their domestic dominant position in the face a of trade war and an unstable world economy.

However, one must note the dynamism of Asia, which in a few decades has established itself as the new centre of global growth has deeply modified the In${ }^{6}$ There is a vast literature on China and the United States hegemonic rivalry from a war-is-inevitable standpoint to more nuanced outcomes of economic interdependence and multipolarity. See among others: Allison, 2015; Shambaugh, 2013; Achary, 2018. 
ternational Division of Labour (IDL) in which China played a unique role, making its imports of components and commodities the bridge between its Asian neighbours and the global export markets for finished goods. China's economic powerhouse has been built on its almost absolute control of the low technological link in the supply chains. However, under the rule of Xi Jinping and its vision "China 2025" of a modern and "moderately prosperous country", the country has been moving upward on the supply chain so it can escape the "middle-income trap" that so many countries face today (Ding \& Li, 2017) ${ }^{7}$. As it stands today, globalization doesn't seem to offer a way out of this trap, and multilateralism is seen as a headlong rush forward that benefits advanced economies only. China's trade and economic policies and initiatives-the One Road, One Belt Initiative, the Asian Infrastructure Investment Bank and other institutions or its fast-expending foreign direct investments-are geared to achieve that goal but in a way that favour a mercantilist zero-sum game of economic exchanges or, at least, a propensity to make the largest possible relative gains at the expense of the common good.

President Trump is changing the modus operandi, at most, by returning to bilateralism in which national security and economic gains displaced reciprocity and the rule of law. The United States, he believes, will be able to strengthen its negotiating power and reinforce its position in the world economy, a position that would have been weakened for three reasons: the multilateralism of the mega-economic partnership agreements like the TPP or the projected United-States trade agreement with the EU, the obsolescence and "unfairness" of the North American Free Trade Agreement (NAFTA), and the presence of "cheaters" or countries who abuse the system by getting more than their fair share of prosperity, of course, at the expense of the American workers.

Therefore, for these three reasons, President Trump withdrew the United States from the TPP agreement on January 23, 2017; forcefully renegotiated NAFTA from a security standpoint by combining access to the American market with immigration issues and by imposing new rules that clearly undermined the WTO compact; and, finally, imposing tariffs and sanctions on many countries based on vague and unsubstantiated security concerns so Washington could negotiate bilateral agreements with countries on the receiving end of Trump's bullying behaviour. There is no doubt that Trump's actions have exacerbated economic tensions around the world. Some have lamented it has given China a free hand in Asia and legitimized its trade policy-which takes its full meaning in the OBOR project-whose cornerstone is not the rule of law but a set of idiosyncratic rules and institutions that are closely linked to domestic political prerequisites that consolidate Chinese communist party rule (Kurik \& Menon, 2018; Narine, 2018). The conclusion of CPTPP negotiations has possibly cooled down Beijing's enthusiasm for its own hegemonic endeavour in Asia-Pacific as it remains an agreement that has the potential to contain quite substantially the ex${ }^{7}$ Very few countries around the world have managed to escape the middle-income trap, most are in Asia, Singapore, Taiwan and South Korea being the best-known cases. 
pansion of Chinese economic might, rules and institutions. But in return, it reinforces China's world view of American decline as Trumplacks the ability to bring the 11 members of the TPP with it in its effort to contain China by threats, tariffs and bilateralism instead of Obama's emphasis to do it trough level playing fields rules, compliance and multilateralism.

\subsection{The Functionalist Explanation}

A second series of analyses are rather part of a technical, managerial and functionalist view of global competitiveness. Focused on the needs of global firms and foreign direct investment (FDI) in the era of globalization, these analyses are connected to the theory of the flying geese (Hatch, 2010) or the work of the British school $^{8}$, which claims that states play a strategic part to ensure national competitiveness, but if they "carry" their national firms' interests in their trade policy, states remain subordinate actors making sure that the growth and well-being of their own firms are prioritized, especially in regional and international economic agreements (Cox, 1992). In this way, FDI takes on a strategic character: it helps to circumvent barriers to entry, gain access to markets and technology, link alliances and create business networks, and so on. FDI has become central to the control and exploitation of value chains on which resided the competitiveness of global firms. Value chains provide them with strong productivity and competitiveness gains based on the territorial specialization of the various phases of production (Baldwin, 2011).

This gives rise to a "race" for national positioning along the value chains. According to the famous "smile curve" (Figure 1), the more advanced countries tend to concentrate upstream and downstream activities, such as research and development, financing and distribution, i.e. higher value-added functions, while emerging economies often perform intermediate functions, including machining, manufacturing and assembly. This vision can be misleading: it hides state's efforts to climb the value-added ladder, like Japan, South Korea or Taiwan have done in the past. In this era of globalization, trade agreements are considered as powerful drivers of competitiveness, not only to expand the potential market, to clarify rules, to promote FDI and technology transfer, but also to set the standards of the level playing field (OECD, 2013). The TPP and its newest version, the CPTPP, are no exception: they place states and firms' expectations at a much higher level of regulation'.

The scope and design of the CPTPP is a clear validation of this functionalist point of view. It belongs to a third generation of trade agreements, similar to the Canada-EU Comprehensive Economic and Trade Agreement (CETA) in force since September 2017, the first of its kind. Thus, in addition to "traditional" issues such as tariffs cuts, market access, intellectual property, and government

${ }^{8}$ Stopford, Strange and Henley, 1991; Strange, 1996; Cox, 1992.

${ }^{9}$ This is the argument put forward by a Vietnamese diplomat involved in the CPTPP negotiation to justify Vietnam participation. Discussion with the authors, in Hanoi, November 2018. 


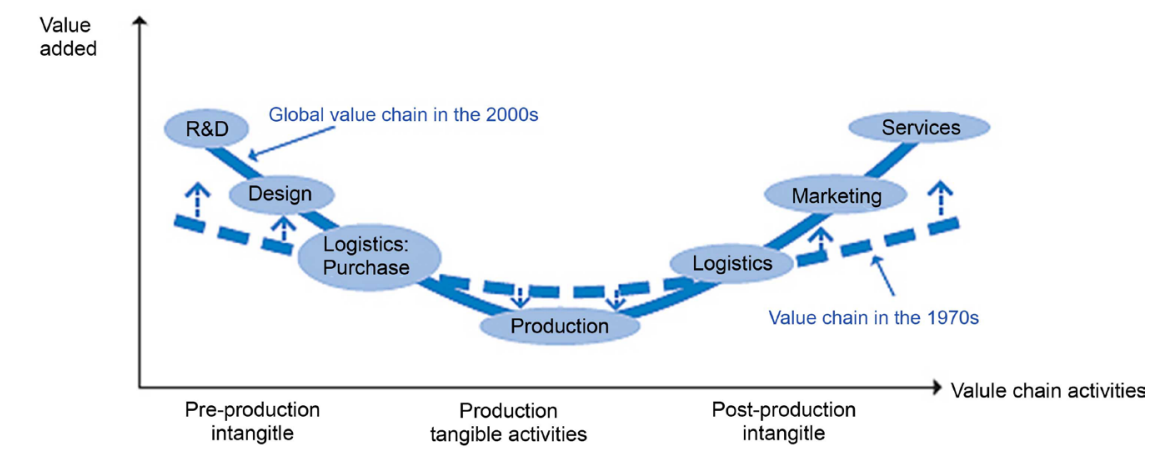

Source: "Interconnected Economies Benefiting from Global Value Chains". OECD2013.

Figure 1. The smiling curve value distribution along the global value chain.

procurement, the CPTPP draws its originality from the emphasis placed on production conditions by devolving chapters on cross-cutting issues such as sustainable development, the digital economy and labour (Deblock \& Lebullenger, 2018). But above all, according to Christian Deblock and Guy-Philippe Wells, the CPTTP adds another layer of complexity with the inclusion of institutional regulatory harmonization mechanisms aimed at interoperability and interconnection that goes much further than just integration, the traditional leitmotif of trade agreements (Deblock \& Wells, 2018). If the aim is to ensure the de-compartmentalization of territories and markets (95\% of tariff lines will eventually be reduced to zero in the CPTPP), the agreement aims above all at greater fluidity along value and production chains and the formation of transnational enterprises networks. The СРТPP and third generation agreements more generally thus meet the demands of an increasingly globalized and interconnected economy and recognize that globally defined competitiveness is what firms are reaching for. Consequently, their attempts to harmonize and modernize trade rules on an inter-regional level creates safeguards against both potentially negative national withdrawal and the WTO's failure to move forward with a new global agreement and the organization creeping parochialism in trade issues.

These analyses are effective in explaining the CPTPP and the major issues surrounding it. Within the larger context of the US-China trade rivalry, the CPTPP, at the risk of oversimplifying, is as much a tool to contain China, as it is one to promote the interests of global firms. These two perspectives are complementary, but nonetheless, don't grasp the fact that the CPTPP can be understood as a tool to reinforce the institutionalization and the multilateralization of Asia-Pacific and, in a roundabout way, China itself. First, institutional weakness characterizes Asia-Pacific economic integration-as the low degree of institutionalization of the APEC forum has showed so well as it failed to liberalize and expand trade flows across the Pacific. Asia-Pacific (and East Asia more specifically) has mostly been defined by open regionalism, low institutionalization and weak legalism. The CPTPP is thus an expression of a common desire to establish 
trade rules based on liberal multilateralism, free trade, the rule of law and legal institutions that can not only contain Chinese power (and now American bilateralism since Donald Trump's election to presidency) but to create a rules-based liberal economic order. Aggressive unilateralism is not unknown to American trade policy and traditionally. It has been addressed within the confine of the WTO Appellate body or, in some case, in national courts and diplomatic talks, thereby limiting its negative effect on growth. The trade dispute between Japan and the United States in the 1980's and 1990's is representative of that situation (Pekkanen, 2015). Today however, aggressive unilateralism has degenerated into a trade war with the potential to bring havoc in the world economy. The potential of the CPTPP to offset these tendencies is limited first, because of the United States withdrawal and second, since it can tame economic rivalry only within a clear and transparent legal framework that takes time to put in place. Countries' behaviour within the CPTPP and with their non-CPTTP partners can only change so fast. Incremental progress to adopt the rules and the "spirit" of the CPTPP is not inevitable. On the contrary, it will be subject to the contingency of a liberal order in jeopardy. To succeed however, and this is our second point, China doesn't need to be contained-implying that the rise of China is a threat to global prosperity and security, which is not the case-but needs to be institutionalized and multilateralized and brought within the confine of a liberal world order as an equal partner. The promises of China accession to the WTO in 2001 have not materialized-it has not become a liberal economy among others expectations (Economy, 2018). On the contrary, China remains wary of the WTO and its reluctance to engage the process of negotiation within the organisation is coming from the fear that that it will have to make further concessions-for example because of unfavourable rulings by the Appellate Body-that will damage its national economic structure. China has not taken a position within the WTO commensurate to its global might (Jones, 2015).

\section{Legitimacy of the CPTTP as the World Order Is Changing}

The Western domination of the international order is an historical aberration, an exceptional and temporary situation. The global economy, in its "longue durée", has always been dominated by China for 5000 years, wrote Andre Gunder Frank (1998). As the world economy's center is moving back to China, it is not clear at all if the resulting process is the decline of the West, but we argued that coming along is the expansion of a "parallel" international order. Emerging economies recognize the presence of a strategic environment that promotes the refocusing of the global economy on China. It does not oppose the existing liberal order but refuses to see it as the principal that direct integration and interdependence, because it imposes hierarchical constraints on the expansion of influence and power on some countries more than others. China therefore prefers to establish international institutions that may appear to be complementary to current ones. Their existence strengthens both China's influence on world eco- 
nomic relations and its autonomy with respect to the existing order. China's trade policies can be linked to non-liberal values or principles (Boyle, 2016), but the fact remains that we do not have a clash between two systems, one democratic and the other authoritarian, but a struggle over the rules of interconnection and interdependence.

The smaller countries of the CPTPP like Vietnam or Malaysia were quick to recognize this situation and adjusted accordingly. They have a lot to gain from multilateral agreements, especially for Vietnam as it is expanding rapidly its industrial base with massive foreign investment. The original version of the TPP was precisely a response to the emergence of this parallel Chinese order or at least a profound recognition that China has hegemonic inclinations in Asia. The agreement facilitated consensus on the rules to be adopted in Asia-Pacific. On the other hand, with the US withdrawal from the TPP and Trump's protectionist threats, the other eleven partners fear that the United States will abandon its role as an advocate of the liberal international order, or even ensure regional stability, to focus on its short-term economic interests. But what everybody can agree on is that economic interdependence is intensifying through value chains but the legitimacy of rules and institutions that will govern the world economy in the $21^{\text {st }}$ century are not yet universally recognized. That is largely due to the absence of a benevolent hegemon with the power to give legitimacy to a certain set of rules. The struggle is open to what rules and institutions will manage the growing interconnection and interdependence of national economies, especially as Washington is keen to free itself from its own rules and responsibilities and thereby increase its economic gains on the short term. The CPTPP still appears to be a compromise in this struggle, pending the evolution of the strategic environment that may well divide the Asia-Pacific rather than strengthen its economic relationship.

\section{The Transformation of American Trade Policy for China and Asia}

The United States has a complex relationship with China, which combine mistrust, economic and military rivalry and a very high level of economic integration that has been tremendously beneficial for both countries. Neither the United States nor China has any other bilateral relationship that could be considered more strategic to their respective futures. The United States' pivot to Asia launched at the time of the Obama Administration must be understood within the complexity of this bilateral relation and it cannot be reduced to a military move. The objective was twofold: to contain the Chinese challenger economically and militarily on the one hand, and to open a strategic dialogue to bring transparency and trust to this relationship (Clinton, 2011). The TPP was the ultimate tool as it did both and, ultimately, we can imagine the success of this policy if China had joined the TPP just like it joined the WTO in 2001. Chinese accession to the TPP would have probably imposed major policy reforms to elimi- 
nate "distortions" caused by government interventions. We will never know if China would have had to face a similar "discriminatory accession protocol" to the TPP as the one imposed on the country to join the WTO, which had "many unprecedented anti-disruption provisions", loathed, even now, by officials inside the CCP. The promise of gaining the market economy status 15 years after joining the WTO in 2001 was one of these provisions despised by Chinese officials (Jones, 2015). The fact that it was denied by President Obama in 2016 probably made things worse, but in return it was an attractive incentive for Beijing to join the TPP. Moreover, the TPP was set so Vietnam-who doesn't have the status of a market economy-could show the way with major labour reforms among others to gain this status (Morrison, 2019). It was an extraordinary gamble by the United States, as Vietnam has followed closely the Chinese path to a "market socialist economy" and never the other way around.

It was then no surprise that the US withdrawal of the TPP created disarray within Asia. In addition to the Trump administration's statements that left doubts in the mind of many regional leaders about the American willingness to defend its Asian allies in the event of armed conflicts with China, the withdrawal accentuated the perception that a much-desired balance had just disappeared in favour of China's position in the region.

In this respect, the ratification of the CРTPP had an obvious tactical element. It politically isolates Washington, while leaving, through its membership formula, the door open for the United States to re-join the CPTPP. At first, this hypothesis was not far-fetched because American interests in Asia-Pacific are so profoundly anchored to a open and free region that it would become illogical for the United States to stay on the sidelines and watch the TPP transform the rules of the game without them. Did President Trump, on the sidelines of the Davos Summit in 2017, say that the United States might be interested in joining an "improved" TPP? ${ }^{10}$ The TPP countries were demonstrating the autonomy of their respective trade policies in the face of the Trump administration's protectionist tendencies and questionable trading practices, but they could not have been more wrong on the return of the United States in the TPP. The Trump administration has put an end to liberal internationalism, the one that has guided the United States trade policy since the end of the Second World War. Trump's launch of a trade war with China was made possible because Washington relinquished the long-held idea that the imposition and removal of tariffs are issues to be taken at a multilateral level, and based on reciprocity, trust and mutual gains, rather than electoral considerations. Washington's preference for bilateralism has borne fruits, at least in the minds of the people working inside the Trump administration. Even the renegotiation of NAFTA has taken a bilateral twist with Washington negotiating at times separately with Mexico and Canada. Thus, the question remains: in the face of the United States preferences for bilateralism, the high value the members of the CPTPP granted to this new set of ${ }^{10}$ The Japan Times, January 27, 2018. 
trade rules might not be enough to offset Trump's effort to make bilateral trade agreements the dominant norm in trade policies.

\section{Global Value Chains and Peripheral Integration}

The CPTPP is geared towards value chains and production networks as the "cumulative rule of origins" has been adopted to facilitate exchange of intermediary goods, parts and components as they can be "traded tariff-free" (Solis \& Urata, 2018). With the possible exception of Japan, none of the signatories of the CPTPP can claim to be a global production hub that structures and feeds global value chains, such as the United States, Germany and China (World Bank, 2017). This does not mean, however, that the members of the CPTPP do not participate fully in the various value chains or, on a national basis, do not control a sector or even several sectors, on the contrary. Table 1 measures "the share of foreign valued added embodied in a country's gross export" (i.e. the backward global value chain integration ratio) and "the extend to which a country's valued added is used by its foreign partners for their own export production" (i.e. the "forward participation ratio"). Most signatories participate therefore to varying degrees in the value chains. They do however appear on the defensive when it comes to normative and regulatory governance. More often than not, they have to accept rules issued by the big global hubs (Rules Takers) rather than playing according to their own rules (Rules Makers); and, for the time being, as we have emphasized, they prefer strict legal rules found in multilateral agreements or in

Table 1. CPTPP: national participation ratio in value chains (\% of Gross Exports) (2011).

\begin{tabular}{ccc}
\hline Country & Downstream & Upstream \\
\hline Australia & 14 & 30 \\
Brunei & 4 & 43 \\
Canada & 23 & 19 \\
Chile & 20 & 30 \\
Japan & 15 & 33 \\
Malaysia & 40 & 20 \\
Mexico & 32 & 15 \\
New-Zealand & 17 & 17 \\
Peru & - & - \\
Singapour & 42 & 20 \\
Vietnam & 36 & 16 \\
& & 25 \\
United States & 15 & 16 \\
China & 32 &
\end{tabular}

Charles Cadestin, Julien Gourdon and Przemyslaw Kowalski, "Participation in Global Value Chains in Latin America: Implications for Trade and Trade-Related Policy", OECD Trade Policy Papers, no. 192, OECD Publishing, Paris, October $11^{\text {th }}, 2016,93 p$. 
the WTO than norms and rules reflecting China's whims and self-interest or those of Trump for that matter.

That said, it is recognized that Latin American countries are far less involved in global value chains than North America or the Asia-Pacific (Blyde, 2014). It is in the Asia-Pacific region where the value chain model regains its most complete forms; in fact, ASEAN countries have played their cards particularly well, to integrate manufacturing into the Japanese, Korean, China Taiwanese, European, American and increasingly Chinese value chains (De Backer \& Miroudot, 2014). In particular, they specialise in the manufacture of components and parts for assembly in China (Mottet \& Jetin, 2016). Because of NAFTA, North America is in the middle of these two extremes, apart from the automotive, energy, electronics and highly integrated services sectors, we cannot talk as much about of a networked economy as integration is based on the ubiquitous presence of American subsidiaries, the Mexican re-export sector (maquiladoras) being the best example (Arès et al., 2016b).

In fact, in its relationship with the Asia factory, not to say Chinese, Latin American countries again seem to face a pattern of central-periphery specialization (Bernal-Meza, 2016). In return for FDI, particularly in commodities (mining, agriculture, energy) and bilateral loans, China is flooding domestic markets with low-cost manufacturing products at the risk for Latin American countries of deindustrialization and re-primarization. The observation also applies-but in very specific national contexts-to Australia, Canada, New Zealand and to a lesser extent Mexico. Highly competitive in the manufacturing sectors, Asia would offer real market opportunities only in terms of commodities, services and engineering. However, these countries keenly recognize China's trade potential, and wonder how to establish a balanced partnership without falling into the orbit of Beijing and the Chinese Communist Party.

\section{The New Leaders of the International Trade Order}

\subsection{Japan in the CPTPP, with or without the United States}

Following the withdrawal of Washington from the TPP, Japan actively promoted a TPP-11 while continuing to negotiate trade agreements with the EU and several Asian countries under the ASEAN + 6 Regional Comprehensive Economic Partnership (RCEP). The protectionist shift in the White House does not seem to have undermined Japan's desire to achieve its trade liberalization goals (to ensure that $85.8 \%$ of its foreign trade is covered by FTAs) and to continue its integration into globalization to revive the country's economic prosperity on a solid and sustainable basis (METI, 2018). Since then, Japan and the EU signed an FTA in July 2018, and Tokyo is trying to bring the difficult and highly secretive RCEP negotiations to a conclusion by the end of 2019 .

Japan has for some time been a new leader in trade policy, an unexpected role due to the usually "reactive" nature of its foreign policy. This is not surprising, however, if we look at its business and trade strategies in more detail over the 
past decade. First, with regard to Asia, foreign policy has always been very innovative and Japan has for more than 60 years been able to "reinvent" the nature of its relations with the countries of East Asia in order to respond to the challenges and crises that have marked relations between them (Chachavalpongpun, 2014). Each time, relations with ASEAN countries have been deepened and extended to new areas and new institutions have been created to strengthen the processes of economic integration on a regional basis with globalization-induced economic competition as the framework that defines these processes. The CPTPP can evidently be included in this process of innovation (Boulanger, 2019).

Secondly, for a decade, but especially since Shinzo Abe came to power in 2012, Tokyo has developed a comprehensive strategy aimed at "multilateralizing" (through international regimes and organizations) and "institutionalizing" (trough norms and rules) Chinese power, or even curbing its hegemonic intentions, to bring it into a liberal international order that is weakened by the emergence of a parallel order under Chinese influence. The new institutions and rules put in place by China are not always in line with the universal principles of the liberal order, and Japan is trying to prevent these differences from weakening its influence in Asia, which is already jeopardized by its demographic decline and the stagnation of its economic capacity (Boulanger, Forthcoming 2020).

Third, Japan has adopted a "defensive liberalism" (Lavina, 2015: p. 75) approach in its foreign policy-which others have referred to as the Abe doctrine (Hughes, 2018) - that closely links the promotion of democracy, the rule of law and free trade with its strategy of neoliberal integration into Asia (and globalization more generally) in the form of economic partnerships. Prime Minister Abe in 2013 said that Japan could not afford to retreat; demographic decline meant that it was in the national interest to turn Asia-Pacific into a region where goods, services and investment move freely ${ }^{11}$. Partnerships must strengthen value chains and ensure that, in the hierarchy of national economies, there must be, in Masao Maruyama's words, a form of equality in the "similarity of economic models" (Murayama, 1974), while China does not seem to be interested in overcoming its new mercantilist's authoritarian practices and institutions.

The theory of new liberalism informs us that conflicts can arise despite a high degree of interdependence, especially when there are significant differences in social identities and in the internal configuration of economic relations (Moravcsik, 2008). Japan's strategy is to reduce these differences because of its opening up to trade and the transformation and economic deregulation of its territory. In fact, it cannot succeed in its "third opening" of the modern era, without hoping for some form of reciprocity from its Asian partners, particularly China. Tokyo's defensive liberalism is therefore intended to prevent China from increasing its autonomy to such an extent that it could have the free field to put in place idiosyncratic rules on which it could lay its dominance of parallel order and possibly escape the middle income trap without a transition to a liberal

\footnotetext{
${ }^{11}$ Kantei, 2013.
} 
economy and political institutions.

\subsection{Continuing Economic Integration and Defensive Liberalism}

In the late 1990s, in particular, following the Asian Financial Crisis (AFC) of 1997, Japan's economic growth strategy was driven primarily by the achievement of deep integration into the East Asian region. This strategy corresponds in every way to the requirements of Japanese firms-due among others to the endaka (the continuous increase of value of the yen between 1985 and 1995) - that had invested heavily in their Asian industrial production networks, thus contributing not only to regional integration but also to the establishment of an export platform that made Japanese firms highly competitive in global markets. For example, for the Ministry of Economy, Trade and Industry (METI), Asian and Japanese economies were forming a "single economic entity", a kind of continental economy if you will, where "Asia is no longer overseas" (Hatch, 2010: p. 102). The harshness of Japan-American trade negotiations throughout the 1980s and 1990s also prompted Japan not to eliminate its neo-mercantilist practices (which will remain in place for several years, at least until the AFC, but to reduce bilateral tensions by relocating industrial production to the America (especially for the automotive industry) and Asia, thus hiding Japan's real share of the overall trade deficit in the United States.

This integration strategy appeared relatively weak with the emergence of globalisation and in particular with the AFC, which shook the archipelago harshly. This integration into Asia, which continued to be inspired by a tight neo-mercantilist model, was quickly abandoned in favour of a free trade policy, with emphasis on the signing of economic partnerships. Japan was somewhat inspired by Frederich List, who suggested in the 19th century that a great economic power should inevitably prefer free trade to narrow economic nationalism (List, 1966 [1841]). Up to the AFC, Japan was torn between its defence of the Asia-Pacific Economic Forum (APEC) - the culmination of a decades-long diplomatic effort to structure Asia-Pacific on an economic basis-and the "appeal of Asia" where it has influence commensurate with its status as the leading economic power. Three events permanently diverted Tokyo from Asia-Pacific to focus on Asia: first, the failure of APEC and its trade liberalization and facilitation programme in the late 1990s; second, the AFC which induced a regional effort for financial and monetary cooperation, led by Japan; and third, the successful integration of Burma, Vietnam, Laos and Cambodia into ASEAN. Japan then chose to link its future prosperity and security to ASEAN + 3 and ASEAN + 6. The TPP doesn't take Japan back to the APEC vision of the region, but to a new one, the "Free and Open Indo-Pacific", which is more a strategy, than a new vision of an extended East Asia, whereby the Chinese new rivalry is now the main source of concern. Trade liberalization should be achieved in a context with no economic and security threats to the liberal order in Asia-Pacific, and also the Indo-Pacific. 
Japan has been pursuing the deepening of regional economic integration since the 2000s in a post-developmental perspective, in which the regional division of labour (RDL) is structured on a free trade basis in order to optimize the exploitation of value chains ${ }^{12}$. Until the 1990s, the RDL was seen from the perspective of the theory of the flying geese with Japan, the leading goose, through its massive FDI and technology shedding, pulled the economic development and growth of the ASEAN countries. The insertion of four new "geese" within a sub-formation (Myanmar, Laos, Cambodia and Vietnam) reinforced this "harmonious" model, which provided a theoretical rationality for the expansion of Japanese firms in Southeast Asia (Staples, 2008). This model promised not a rotation at the head of the formation, but a flattening of the V-formation, as the ASEAN countries could envisage catching up with Japan, as Japan had caught up with the Western industrial powers during the $20^{\text {th }}$ century (Staples, 2008).

If METI officially abandoned the flying geese model in the early 2000s, it is because today the RDL relies on the exploitation of value chains, fragmentation of production processes and intra-regional competitiveness based on trade in parts and components which represents $60 \%$ of regional trade, the highest rate in the world, ahead of the EU and North America (METI, 2018)..$^{13}$ Japan is still the leader of this formation, but its dominance of industrial production-while taking advantage of the "captivity" of Asian countries to Japanese technologies, equipment and products-has been severely tested in terms of added value with the technological advances of several ASEAN economies and especially China (METI, 2018; Hatch, 2010). Economies can quickly dominate certain industrial sectors without joining Japan in terms of GDP per capita, as suggested by the flying geese model. The leading goose, Japan, "may be out of breath"-while in the early 1990s Bangkok or Kuala Lumpur were literally "quasi-imperial outposts" of Japan's economic power (Hatch, 2010) - but Japan does not seem convinced that China will take the lead of the formation until its power has been multilateralized and institutionalized, and has agreed to play according to Japan and ASEAN rules of open regionalism, which are essential to the competitiveness of the Asia factory in global markets.

This shift to a free trade policy aimed to continue the process of regional integration on a stronger legal basis. It sought to respond, first, to the emergence of a new, highly competitive RDL based, as we said, in part on the trade of parts and components. Second, to protect Japanese firms, particularly those active in Asia, from the vagaries of globalization through economic partnerships. Third, to adjust the reforms of the internal economy to globalized competition imperatives. Japan was gradually shifting from a neo-mercantilist economy to a liberal and de-regulated economy where competitiveness was no more measured in strictly national terms (i.e. competition between domestic firms without worrying about their position in foreign markets), but in global terms (competition with other firms in the world).

\footnotetext{
${ }^{12}$ On value chains in South East Asia, see: Mottet and Jetin, 2016.

${ }^{13}$ See also: McNamara, 2009, 57-59.
} 
In many cases, highly competitive firms in Japan were actually much less competitive globally or not even present on foreign markets, a situation coined the "Galapagos Syndrome": firms are operating in a sector of the economy that has reached a high level of technological development while being cut off from the global market. These companies-including mobile telephony, medical equipment, electronic money or services-are unable to carve themselves a place on foreign markets because, like the species populating the Galapagos, technological evolution occurred in isolation from international standards and norms or because the product or service offered contains characteristics specific to Japanese society. Japan is therefore pursuing both liberalization and deregulation of its economy and foreign trade in order to encourage these firms to adapt to globalization rather than limiting themselves to the local market (Yoshikawa, $2010)^{14}$.

Japan cannot envision the success of its new liberal model of national prosperity if China does not adopt more liberal and transparent economic policies. Japan economic growth will be hard hit if a parallel world order emerges in which the level playing field tilts in favour of neo-mercantilist policies. Moreover, Japan's dependence on foreign trade has increased with the almost disappearance of its nuclear sector, forcing it to significantly increase its manufacturing exports, FDI and its technological presence on value chains to pay for its vast imports of natural gas and oil. The fact that Japan has achieved a trade surplus five years after the 2011 Fukushima accident indicates that Japan's trade strategy remains deeply associated with rising exports. In short, Japan has become what was predicted a long time ago: a liberal "trading state" that is closely integrated into the global economy and whose prosperity is commensurate with its external wealth. Japan cannot remain the world's largest creditor country, with net assets of $\$ 3100$ billion, if multilateralism collapses.

In its original form, the TPP was the logical continuation of this strategy, which demands more than ever the multilateralization of China. The US withdrawal was a severe blow for Japan, as Tokyo could envisage with the TPP a regulatory containment of China's economic power while continuing the ASEAN + 6 RCEP negotiations, of which China is a member. The failure of the TPP had posed a serious problem. The TPP could, on the one hand, lead Asia to higher standards-which the ASEAN countries recognized-and, on the other hand, promote China's multilateralization and institutionalization with the prospect of China adjusting itself to the new TPP's rules and regulation and keeping ASEAN countries away from a potential parallel order.

The CPTPP Tokyo believed, should have made the United States recognize the cost associated with its misguided and blundering trade diplomacy, especially its call for a bilateral Japan-US trade agreement. After the American withdrawal from the TPP, the Japanese diplomatic corps were not in a mood to put again their heart and soul into a new round of trade negotiation with the United ${ }^{14}$ See also: Boulanger, 2015: p. 49. 
States and it was for them counterproductive to do so. A bilateral trade agreement would eliminate the positive externalities generated by the CPTPP and it legitimized bilateralism at the expanse of multilateralism and the defense of the liberal world order. Japan's rejection of a trade deal with the United States did portray Japan - with the EU-as the last champions of multilateralism, and yet, American pressure have finally brought Tokyo to the negotiating table while President Trump launched threats of new tariffs on Japanese exports in speeches advocating national security and economic gains at the expense of reciprocity and the rule of law.

Japan's trade strategy is thus at a crossroads. The toughness and uncompromising behaviour of American negotiators could well bring Japan to re-evaluate its relationship with China. The most recent thaw in China-Japan relations-and maybe the end of their conceptualization as hot economics and cold politics-could make Tokyo recognize that it has to align itself with China. If Japan's foreign markets tend to close or risk being lost to competition, why not turn towards its century long "natural market" and accept the fact that in a global trade war, there might be congruence of economic interest between Japan and China. Indeed, at the Osaka G20 summit, in June 2019, Xi Jinping and Shinzo Abe have discussed their effort to stand together for the sake of multilateralism and free trade in the face of the liberal as well as the conservative backlash against globalization that is weakening political regimes and could very well bring the fragmentation of the world economy (Yoshida \& Osaki, 2019). But we can doubt this newfound friendship between Tokyo and Beijing. The drawback is that China would have the necessary leeway to become the first non liberal global hegemon in modern history, legitimizing "once again" the positive link between capitalism and authoritarianism, which is not a good thing as around the world, authoritarianism increasingly appears as a legitimate solution to the numerous shortcomings of democracies, even in Japan (Foa \& Mounk, 2017). Rather, Tokyo preferred to maintain its privilege and close relationships with the United States and other liberal democracies than to "embrace" Xi Jinping's China Dream.

It is then no coincidence if officials from Japan, the United States, Australia and India met in Bangkok a month before the G20 summit in June 2019 to take stock of the situation and assess both Tokyo's strategy for a "free and open Indo-Pacific" and their "collective efforts" to push forward with it. This strategy is the most recent answer to China's idiosyncratic trade policy. This strategy aims to entrench the rule of law in the region to bring Beijing (and it is a back-door opportunity to include other Asian countries as well) to adopt a minima transparent national policies, common trading and investment rules, common regulations for infrastructure, forestall drifting from democratic norms and avoid the use of illegitimated economic tools like punitive import tariffs (Green, 2018). This is a large endeavour, but Japan is pushing on: it still presents itself to the world as a strong advocate of multilateralism, which is reassuring in our present troubled world, agitated by nationalism and populism. 


\section{Final Considerations: CPTPP as a Transitional Agreement}

For many partners of the CPTPP, particularly in Asia, the US withdrawal meant a sharp decline in potential gains from the Trade Agreement, but it is too early to tell if for Japan and the other CPTPP partners, their objectives will prevail. With this in mind, in its current formulation, the CPTPP is only a transitional trade agreement. More specifically, it is a tactical position in the current RCEP negotiations, or other negotiation frameworks, to bring about Chinese recognition of the ascendancy of the СРТPP rules and norms over its own idiosyncratic trade policy. It has the additional benefit of compelling Washington to return to a more nuanced trade policy to face the reality of value chains and the fact that multilateralism today is also more about sharing production capacities than the protection of national industries. It is not yet clear if the CPTPP has had a decisive influence on the preliminary agreement reached by the RCEP members in November 2019 following India's withdraw from it. However, it is quite obvious that China has won a decisive battle in its hegemonic confrontation with the United States: RCEP principles and norms being generally below the CPTPP's ones. Still Trump seems not to be aware of trade regulation progress in Asia and prefers to maintain its hard bilateral stand against both the United States rivals and allies.

\section{Conflicts of Interest}

The authors declare no conflicts of interest regarding the publication of this paper.

\section{References}

Achary, A. (2018). The End of the American World Order. Cambridge: Polity Press.

Allison, G. (2015). The Thucydides Trap. In R. N. Rosecrance, \& S. E. Miller (Eds.), The Next Great War? The Roots of World War I and the Risk of US-China Conflict (pp. 73-79). Cambridge: The MIT Press. https://doi.org/10.7551/mitpress/9780262028998.003.0006

Arès, M., \& Boulanger, É. (2016a). Christophe Colomb découvre enfin l'Asie. Intégration économique, chaînes de valeur et recomposition transpacifique [Christopher Columbus Finally Discovers Asia: Economic Integration, Value Chains et Transpacific Reconfiguration]. Montreal, Athena.

Arès, M., \& Deblock, C. (2016b). De l'intégration à l'interconnexion. L’Amérique du Nord un espace économique en recomposition', [From Integration to Interconnexion: North-American as an Economic Space in Reconfiguration]. Outre-Terre, No. 46, 320-348. https://doi.org/10.3917/oute1.046.0320

Baldwin, R. (2011). Integration of the North American Economy and New-Paradigm Globalization. In A. Sydor (Ed.), Global Value Chains-Impacts and Implications (pp. 51-92). Ottawa: Foreign Affairs and International Trade Canada. https://doi.org/10.2139/ssrn.2179659

Bernal-Meza, R. (2016). China and Latin America Relations: The Win-Win Rhetoric (pp. 27-43). JCIR Special Issue.

Blyde, J. (2014). Synchronised Factories: Latin America and the Caribbean in the Era of 
Global Value Chains. VOX CEPR's Policy Portal. https://voxeu.org/aricle/latin-americas-missing-global-value-chains

Boulanger, É. (2015). Multinationales japonaises: Du repli à l'internationalisation discrete' [Japanese Multinational Firms: From Withdrawal to Subtle Internationalization]. Diplomatie, No. 29, 49.

Boulanger, É. (2019). La coopération entre le Japon et l'ASEAN' [Japan and ASEAN Cooperation]. In S. Granger, \& D. Caouette (Eds.), L'Asie du Sud-Est à la croisée des puissances [South East Asia as the Crossroad of Geat Powers] (pp. 163-182). Montreal: Les Presses de l'Université de Montréal.

Boulanger, É. (Forthcoming 2020). Le Japon coincé entre les États-Unis et la Chine: sera-t-il le dernier champion du multilatéralisme? [Japan Trapped between the USA and China: The Last Champion of Multilateralism?]. In M. Arès, É. Boulanger, \& É. Mottet (Eds.), La guerre par d'autres moyens: Regards croisés sur les négociations commerciales au 21e siècle [War by Other Means: Overlapping Perspectives in Trade Negotiation in the 21st Century]. Montreal: PUM.

Boyle, M. J. (2016). The Coming Illiberal Order. Survival, 58, 35-66. https://doi.org/10.1080/00396338.2016.1161899

Chachavalpongpun, P. (2014). Approaches toward Regionalism: Japan, China, and the Implication on ASEAN. In T. Shiraishi, \& T. Kojima (Eds.), ASEAN-Japan Relations (pp. 38-54). Singapore: ISEAS Publishing. https://doi.org/10.1355/9789814519229-005

Clinton, H. (2011). America's Pacific Century. Foreign Affairs, No. 189, 56-63.

Cox, R. (1992). Multilateralism and World Order. Review of International Studies, 18, 161-180. http://www.jstor.org/stable/20097291 https://doi.org/10.1017/S0260210500118832

De Backer, K., \& Miroudot, S. (2014). Mapping Global Value Chains. European Central Bank, The Competitiveness Research Networks (40 p.). Working Paper Series, No. 1677.

Deblock, C., \& Lebullenger, J. (2018). Génération TAFTA. Les nouveaux partenariats de la mondialisation [TAFTA Generation: New Partnerships in the Era of Globalization]. Rennes: Presses universitaires de Rennes.

Deblock, C., \& Wells, G. P. (2018). Coopération réglementaire et accords de commerce' [Regulatory Cooperation and Trade Agreements]. Études internationales, 48, 319-345. https://doi.org/10.7202/1044623ar

Ding, Y., \& Li, X. (2017). The Past and Future of China's Role in the East Asian Economy. Canadian Public Policy, 43, S45-S56. https://doi.org/10.3138/cpp.2016-072

Economy, E. C. (2018). The Third Revolution: Xi Jinping and the New Chinese State. Oxford: Oxford University Press.

Foa, R. S., \& Mounk, Y. (2017). The Sign of Deconsolidation. Journal of Democracy, 28, 5-15. https://doi.org/10.1353/jod.2017.0000

Frank, A. G. (1998). ReOrient: Global Economy in the Asian Age. Berkeley, CA: University of California Press.

Green, M. J. (2018). Japan's “Free and Open Indo-Pacific Strategy” as Grand Strategy. We Are Tomodachi, 29, 28-29.

Hatch, W. F. (2010). Asia's Flying Geese: How Regionalization Shapes Japan. Ithaca, New York: Cornell University Press.

Heilmann, S., Rudolf, M., Huotari, M., \& Buckow, J. (2014). China's Shadow Foreign Policy: Parallel Structures Challenge the Established International Order. China 
Monitor. https://voxeu.org/article/latin-americas-missing-global-value-chains

Hughes, C. W. (2018). Japan's Security Policy in the Context of the US-Japan Alliance: The Emergence of an "Abe Doctrine”. In J. D. J. Brown, \& J. Kingston (Eds.), Japan's Foreign Relations in Asia (pp. 49-60). London: Routledge.

Jones, K. (2015). Reconstructing the World Trade Organization for the 21st Century: An Institutional Approach (pp. 64-66+229-231). New York: Oxford University Press.

Kantei (2013). Press Conference by Prime Minister Shinzo Abe. Tokyo. https://japan.kantei.go.jp/96_abe/statement/201303/15kaiken_e.html

Kantei (Prime Minister Residence of Japan) (2018). Speeches and Statements by the Prime Minister. Tokyo. https://japan.kantei.go.jp/98_abe/statement/201807/_00002.html

Kurik, J., \& Menon, R. (2018). China will Miss the TPP. Foreign Affairs.

Lavina, L. (2015). Ethics and Morality in International Relations. In E. Kavalski (Ed.), Encounters with World Affairs (pp. 75). Farnham, England: Ashgate.

List, F. (1966 [1841]). The National System of Political Economy. New York: A. M. Kelly.

METI (2018). White Paper on International Economy and Trade (pp. 548). Tokyo.

Moravcsik, A. (2008). The New Liberalism. In C. Reus-Smit, \& D. Snidal (Eds.), The OXford Handbook of International Relations (pp. 234-254). Oxford: Oxford University Press. https://doi.org/10.1093/oxfordhb/9780199219322.003.0013

Morrison, W. M. (2019). China's Status as a Nonmarket Economy. Washington DC: Congressional Research Service.

Mottet, É., \& Jetin, B. (2016). L'Asie du Sud-Est et les chaînes de valeur [South East Asia and Value Chains]. In M. Arès, \& É. Boulanger (Eds.), op. cit (pp. 183).

Murayama, M. (1974). Studies in the Intellectual History of Tokugawa Japan. Tokyo: University of Tokyo Press.

Narine, S. (2018). US Domestic Politics and America's Withdrawal from the Trans-Pacific Partnership: Implications for Southeast Asia. Contemporary Southeast Asia, 40, 50-76. https://doi.org/10.1355/cs40-1c

Nathan, A. J. (2016). China's Rise and International Regimes: Does China Seek to Overthrown Global Norms? In R. S. Ross (Ed.), China in the Era of Xi Jinping: Domestics and Foreign Policy Challenges (pp. 165-195). Washington DC: Georgetown University Press.

OECD (2013). Interconnected Economies: Benefiting from Global Value Chains. Paris: OECD Publications.

Pekkanen, S. M. (2015). Japan's Aggressive Legalism: Law and Foreign Trade Politics beyond the WTO. Redwood City, CA: Stanford University Press.

Seib, G. B. (2015). Obama Presses Case for Asia Trade Deal, Warns Failure Would Benefit China. The Wall Street Journal.

https://www.wsj.com/articles/obama-presses-case-for-asia-trade-deal-warns-failure-wo uld-benefit-china-1430160415

Shambaugh, D. (2013). China Goes Global: The Partial Power. Oxford: Oxford University Press.

Solis, M. (2017). Dilemmas of a Trading Nation: Japan and the United States in the Evolving Asia-Pacific Order. Washington DC: Brookings Institutions Press.

Solis, M., \& Urata, S. (2018). Abenomics and Japan Trade Policy in a New Era. Asian Economic Policy Analysis, 13, 106-123. https://doi.org/10.1111/aepr.12205

Staples, A. J. (2008). Responses to Regionalism in East Asia: Japanese Production Net- 
works in the Automotive Sector (pp. 23-26). New York: Palgrave MacMillan.

Stopford, J., Strange, S., \& Henley, J. S. (1991). Rival States, Rival Firms: Competition for World Market Shares. Cambridge: Cambridge University Press.

https://doi.org/10.1017/CBO9780511549830

Strange, S. (1996). The Retreat of the State: The Diffusion of Power in the World Economy. Cambridge: Cambridge University Press.

https://doi.org/10.1017/CBO9780511559143

Stuenkel, O. (2016). Post-Western World: How Emerging Powers are Remaking Global Order. Cambridge: Polity Press.

The Japan Times (2018). Trump Woos Davos with TPP Trade Deal Shift, Says U.S. Is 'Open for Business'.

World Bank (2017). Global Value Chain Development Report. Measuring and Analyzing the Impact of GVNs on Economic Development (pp. 7). Washington DC: World Bank.

Yoshida, R., \& Osaki, T. (2019). Underlining Improved Japan-China Ties. Abe and Xi Meet Ahead of G20 Summit. The Japan Times.

Yoshikawa, N. (2010). Galapagosu ka suru nihon [The Galapagosization of Japan]. Tokyo, Kodansha. 